LAERE MIDDEL ODK

\title{
Elevernes trivsel og mentale sundhed
} - hvad har vi lært af nødundervisningen under coronaskolenedlukningen?

Af Karen Wistoft, Jacob H. Christensen og Lars Qvortrup

Korrekt citering af denne artikel efter APA-systemet (American Psychological Association System, 7th Edition): Wistoft, K., Christensen, J. H. \& Qvortrup, L. (2020). Elevernes trivsel og mentale sundhed - hvad har vi lært af Nødundervisningen under corona-skolenedlukningen. Learning Tech - Tidsskrift for læremidler, didaktik og teknologi, (7), 40-65. DOI 10.7146/It.v5i7.120865 


\section{Abstract}

På basis af et survey for elever og forældre under corona-skolenedlukningen sætter denne artikel fokus på, hvordan nedlukningen påvirkede elevernes trivsel og mentale sundhed, hvilke bekymringer de selv og forældrene havde, hvilke familier der følte sig særligt mentalt udsatte, og hvordan eleverne og forældrene håndterede skolelukningerne. Næsten alle eleverne savnede vennerne, skolen og fritiden, og knap en femtedel følte sig ensomme. Mange af eleverne var usikre på deres egen læring, hvilket kan hænge sammen med, at de arbejdede alene og ikke havde samme grad af kontakt til lærerne som normalt. Samtidig udtrykte også en del af forældrene bekymring for deres børns personlige udvikling og mentale trivsel. Herudover kan der identificeres en sammenhæng mellem elevernes vurdering af deres mentale sundhed og graden af kontakt med lærere og kammerater samt forældrenes vurdering af hverdagen. Endelig vurderede elever, hvis forældre havde lav socioøkonomisk status, deres egen mentale sundhed lavere end de øvrige elever.

Based on a survey for students and parents concerning homebased distance education in primary and lower secondary school, this article focuses on the way in which the corona lock down affected students' well-being and mental health, what concerns students and parents had, which families felt particularly mentally vulnerable, and how students and parents handled the school lock down. Almost all students missed their friends and the school, and approximately 20 pct. felt lonely. Many of the students were unsure of their own learning, related to the fact that students worked alone at home with only a little contact to their teachers. Part of the parents expressed their worries about their children's personal development, well-being and mental health. Students' assessment of their mental health correlated with the degree of contact with teachers and friends. Finally, children whose parents have the lowest socioeconomic status, assess their own mental health lower than average. 


\section{Elevernes trivsel og mentale sundhed - hvad har vi lært af nødundervisningen under corona- skolenedlukningen?}

\section{Introduktion}

Da corona-pandemien brød ud i Danmark i marts 2020 blev skolen, lærerne, pædagogerne, lederne, eleverne, forældrene og skole-hjem-samarbejdet sat under pres. Med meget kort varsel blev alle elever sendt hjem som følge af skolelukninger, og undervisningen skulle gennemføres som hjemmeundervisning. Hurtigt meldte spørgsmålene sig: Hvad betyder dette for elevernes læring, trivsel og sociale relationer, for forældrene der skulle balancere mellem arbejde, hjemmeundervisning og familieliv, og for underviserne der med få dages varsel skulle foretage en digital omstilling og gennemføre undervisning på afstand, og hvilke familier følte sig særligt mentalt udsatte?

For at få svar på disse spørgsmål og for at fastholde en viden om en helt unik periode i folkeskolens historie, udarbejdede vi, en forskergruppe fra Aarhus Universitet og Syddansk Universitet, straks efter skolelukningerne et spørgeskema om elevers og forældres erfaringer fra tiden under corona-nedlukningen. Samtidig henvendte vi os til en lang række kommuner. Aarhus, Frederikshavn, Hjørring, Lemvig, Odense og Svendborg kommuner svarede positivt tilbage, og med disse kommuner lavede vi en aftale om udsendelse af spørgeskemaet. Selv om kommunerne således ikke var tilfældigt udvalgt, kunne vi konstatere, at der er en god geografisk spredning, at både by- og landkommuner er repræsenteret, og at der både er store og små kommuner. Den 1. april blev der lagt et link ud på AULA til alle elever i 3.-9. klasse og deres forældre i de nævnte kommuner. Spørgeskemaet var udformet sådan, at eleverne først skulle besvare et antal spørgsmål - gerne med støtte fra forældrene - og dernæst skulle forældrene 
overtage skemaet og besvare et mindre antal spørgsmål særligt rettet til dem. Både elever og forældre skulle besvare udsagn på en femtrinsskala, ligesom de fik mulighed for i et fritekstfelt at besvare et åbent spørgsmål om det bedste og værste ved situationen under corona-nedlukningen. Fritekstsvarene udgør undersøgelsens kvalitative del. Den er endnu ikke analyseret systematisk, men bliver i denne artikel alene brugt illustrativt. Alle items i den kvantitative undersøgelse omhandlede elevernes og forældrenes oplevelser med nødundervisningen under corona-nedlukningen. Herudover fik eleverne og forældrene spørgsmål, der handlede om baggrundsvariablerne køn, alder, kommune, skole og socioøkonomisk status. Der blev udsendt en rykker straks efter påsken, og den samlede svarperiode var 1. til 20. april. De fleste svar blev modtaget i løbet af den første uge, dvs. op til påsken, hvor skolelukningerne var på deres højeste, og før undervisningen blev genoptaget for de yngste elever.

Efter en frasortering af ugyldige svar bestod datagrundlaget af 5953 svar fra elever, og 4955 svar fra forældre. Med et samlet elevgrundlag i de seks deltagende kommuner på 55.132, giver det en svarprocent på 10,8. Dette er ikke en høj svarprocent, men sammenlignet med lignende undersøgelser, hvor spørgeskemaet ikke udsendes til den enkelte respondent, men distribueres via et link på en webbaseret platform som AULA, er svarprocenten forventelig (Carley-Baxter, Hill, Roe, Twiddy, Baxter \& Ruppenkamp, 2013).

Svarene giver et unikt datamateriale, som er beskrevet i rapporten: "Nødundervisning under corona-nedlukningen et elev- og forældreperspektiv" (Qvortrup, Qvortrup, Wistoft, Christensen \& Lomholt, 2020). Herudfra kan vi blandt andet besvare spørgsmålene: Hvordan påvirkede corona-nedlukningen elevernes trivsel og mentale sundhed? Hvilke bekymringer havde de selv, og hvilke havde forældrene? Hvordan håndterede elever og forældre skolelukningerne?

Allerede ved den første behandling af datamaterialet stod det klart, at undersøgelsen rummer mange oplysninger om elevernes trivsel og mentale sundhed. Elevernes og forældrenes svar er i sig selv informative. Men herudover giver materialet mulighed for at lave analyser, hvor sammenhænge mellem forskellige svar og baggrundsvariable bliver undersøgt. I artiklen vil vi først præsentere nogle af de umiddelbare resultater fra undersøgelsen ved at præsentere svarfrekvenser deskriptivt, dvs. det som data i sig selv fortæller os. Dernæst vil vi præsentere en række statisti- 
ske analyser, hvor vi har undersøgt sammenhængen mellem på den ene side børnenes mentale sundhed og på den anden side andre faktorer i form af: Oplevelsen af undervisningen, oplevelsen af klare rammer og struktur, forældres tilfredshed med skolen og lærernes indsats, forældres bekymring over deres børns læring og udvikling, forældres oplevelse af at kunne håndtere situationen, og familiernes socioøkonomiske status. Men før vi kommer til disse analyser, ser vi nærmere på den internationale corona-skoleforskning, der er relateret til trivsel og mental sundhed.

\section{Den internationale corona-forskning}

Som bekendt var situationen i Danmark ikke enestående, heller ikke hvad angår skolesituationen. Verden over lukkede skolerne, og elever kom i hjemmekarantæne. Det er der allerede skrevet nogle få, introducerende artikler om (Burgess \& Sievertsen, 2020).

Kina var det første land, der blev ramt af corona, og kinesiske studier har allerede vist resultater om såvel hjemmeundervisning som karantæne (Kong, 2020; UNESCO, 202O; Xia, 202O; Xie \& Yang, 2020). Kort fortalt er disse artikler optaget af at identificere praktiske løsninger og præsentere hjemmeundervisningsvejledninger, som fx UNESCO's håndbog om, hvordan man faciliterer fleksibel læring i nødundervisningsperioden. Ingen af disse studier bruger imidlertid elever som respondenter, ligesom de ikke beskriver elevernes perspektiv på hjemmeundervisningen, både som eleverne selv oplever det og sat i relation til andre baggrundsvariable, som fx elevernes socioøkonomiske status.

Os bekendt er der indtil nu kun offentliggjort resultater fra én stor undersøgelse af hjemmeundervisningen under corona-nedlukningen i lande, der ligner Danmark. I Norge har forskerne Astrid Roe, Marte Blikstad-Balas og Kirsti Klette ved Universitetet i Oslo og Cecilie Pedersen Dalland ved OsloMet gennemført en spørgeskemaundersøgelse blandt mere end 4500 ansatte i den norske grundskole, som har haft hjemmeundervisning med eleverne, mens skolerne var lukkede. Et af de interessante fund er, at lidt over halvdelen af eleverne i indskolingen (54 procent) kun havde kontakt med læreren 2-3 gange om ugen eller sjældnere, mens 71 procent af eleverne i udskolingen havde kontakt med læreren mindst én gang om dagen. Det samme kom til udtryk i form af det, der i den normale skolegang hedder mødepligt, og som under corona-nedlukningen i Norge blev de- 
fineret som faste tider for at logge på til lærerens undervisning. I udskolingen havde tre af fire elever mødepligt, på mellemtrinnet var det to af tre elever. Men i indskolingen gjaldt dette bare for en tredjedel af eleverne, og her var det for 27 procent af eleverne tilstrækkeligt at levere opgaver, mens 23 procent overhovedet ikke havde nogen form for rutiner med hensyn til at logge på til skolens netværk eller på anden måde deltage i undervisningens fællesskab (Roe, Blikstad-Balas, Klette \& Dalland, 2020). Især for de yngre elever i Norge har der altså været relativ lidt rutine og skole- og lærerkontakt.

I Danmark gennemførte Danmarks Lærerforening (DLF) på samme tidspunkt som os en survey-undersøgelse med lærere og børnehaveklasseledere som respondenter. Den blev offentliggjort som et notat, og den belyser læreres og børnehaveklasselederes erfaringer fra perioden med nødundervisning (DLF, 2020). Undersøgelsen fremhæver en række problemer i forbindelse med nødundervisning, men påstår samtidig, at lærerne har haft god kontakt til de fleste elever.

Ligesom for de kinesiske studier må man imidlertid notere sig, at hverken den norske eller den danske undersøgelse bruger elever som respondenter og derfor kun indirekte kan sige noget om deres oplevede trivsel og mentale sundhed. På dette punkt bidrager vores undersøgelse med data, der belyser de mest relevante perspektiver på elevernes trivsel og mentale sundhed under corona-nedlukningen. Desuden er vores undersøgelse efter vores vidende den eneste, der har eleverne som respondenter (Qvortrup, Qvortrup, Wistoft, Christensen \& Lomholt, 2020).

\section{Hvordan kan man definere trivsel og mental sundhed?}

Inden vi præsenterer vores egne dataanalyser, er vi nødt til at indkredse begreberne trivsel og mental sundhed.

De få studier af uddannelse og undervisning under corona-nedlukningen, som har berørt elevernes sundhed og trivsel, har været præget af en sygdomsorienteret opfattelse af sundhed, hvor sundhed og trivsel defineres som fravær af sygdom og mistrivsel (jf. fx Brooks, Webster, Smith, Woodland, Wessely, Greenberg, Rubin et al., 2020 og Wang, Zhang, Zhao, Zhang \& Jiang, 2020). For os er det imidlertid vigtigt at anlægge et bredere perspektiv, som ikke er sygdoms- men trivselsorienteret. Det er ikke tilstrækkeligt at undgå, at børnene blev somatisk syge eller 
mistrivedes. Det er også vigtigt at sikre, at børnene så godt som muligt trivedes socialt og fagligt, og at de var mentalt sunde.

Men hvad er forskellen mellem en sygdoms- og en trivselsorienteret opfattelse? Med henvisning til Max Webers begreb om idealtyper som noget, der gengiver et forenklet billede af et komplekst fænomen (se fx Shils \& Finch, 1949), kan man identificere disse opfattelser som to forskellige diskurser: Den sygdomsorienterede og den trivselsorienterede. Den humanistiske sundhedsforskning har i flere år været optaget af at diskutere mentale sundhedsdiskurser (La Placa, McNaugh \& Knight, 2013), og man har forsøgt at redegøre for, hvilken betydning forskellen mellem en sygdomsorienteret og en positiv, holistisk tilgang har for såvel målinger som teoriudvikling (e.g. Dodge, Daly, Huyton \& Sanders, 2012; Forgeard, Jayawickreme, Kern \& Seligman, 2011; Keyes, 2002, 2005, 2009; Keyes, Shmotkin \& Ryff, 2002). Her tager vi udgangspunkt i et begreb om mental sundhed, der defineres som langt mere end fravær af psykisk sygdom eller mistrivsel, og som samtidig også er mere og andet end lykke og tilfredshed, som de holistiske forståelser rummer. I WHO's definition af mental sundhed som "en tilstand af trivsel, hvor man kan udfolde sine evner, håndtere normale hverdagsbelastninger og indgå i positive relationer og bidrage til fællesskabet" (WHO, 2008, 2014) lægges der op til en trivselsforståelse med tre dimensioner: En evne-dimension, en håndterings-dimension og relations-dimension.

Som det er tilfældet med mental sundhed, er der i dag også stor forskel på, hvordan trivsel blandt børn og unge opfattes, omtales og måles. Vi har tidligere identificeret to diskurser, som i særlig grad præger trivselsbilledet. Den ene kan betegnes som en folkesundhedsdiskurs, der har rødder i epidemiologi og forebyggelse. Den anden er en loeringsorienteret diskurs, der refererer til pædagogik og uddannelsesvidenskab. En sammenligning af de to diskurser har vi tidligere præsenteret i kort form i en debatartikel med titlen "A Distinction of Two Discourses Concerning Wellbeing" (Wistoft \& Qvortrup, 2017).

I den sundhedsfaglige trivselsdiskurs, der har præget corona-nedlukningen, defineres trivsel som en risiko- og sygdomsfri tilstand, fx fravær af COVID-19, dvs. en tilstand hvor der er minimal risiko for at blive syg eller for at mistrives. Der er fokus på at undgå negative konsekvenser af såkaldt risikoadfærd: Smitte og smittespredning, tab, sorg eller sygdom (Sundhedsstyrelsen, 2020). Der sættes fokus på smitterisici og mistrivselsrisici. 
Tanken er, at trivsel øges ved at eliminere eller forhindre risikoadfærd (Sundhedsstyrelsen, 2011).

Over for den sundhedsvidenskabelige tilgang står den uddannelsesvidenskabelige eller pædagogiske tilgang. Her defineres trivsel ikke negativt, dvs. som fravær af sundhedsrisici, men positivt, dvs. som tilstedeværelse eller oplevelse af faktorer, der forbindes med trivsel i positiv forstand, som for eksempel elevernes optimisme, forhåbninger, tro på sig selv, tillid til omverdenen og disse forholds indflydelse på deres velbefindende, følelse af overskud, gåpåmod, handlekraft, læring og glæde ved at være sammen med andre. Wistoft og Qvortrup har illustreret forskellen således:

Figur 1.

To trivselsdiskurser.

Kilde: (Wistoft \& Qvortrup, 2017).

\begin{tabular}{l|l|l}
\hline Sundhedsdiskurs & $\begin{array}{l}\text { Definition af trivsel } \\
\text { Risikofri og sygdomsfri tilstand }\end{array}$ & $\begin{array}{l}\text { Fremme af trivsel } \\
\text { Risikoadfærdsreducerende inter- } \\
\text { ventioner baseret på et kausallogisk } \\
\text { paradigme (årsag - virkning) }\end{array}$ \\
\hline $\begin{array}{l}\text { Læringsorienteret } \\
\text { diskurs }\end{array}$ & $\begin{array}{l}\text { Velbefindende, der kommer til } \\
\text { udtryk i følelser af overskud, } \\
\text { gåpåmod, handlekraft, læring } \\
\text { og glæde ved at være sammen } \\
\text { med andre }\end{array}$ & $\begin{array}{l}\text { Involverende interventioner baseret } \\
\text { på et refleksionslogisk paradigme } \\
\text { (ydre påvirkning - refleksion) }\end{array}$ \\
\hline
\end{tabular}

Det er en vigtig pointe, at den offentlige corona-trivselsdiskurs domineres af en epidemiologisk/sundhedsfaglig orientering, som ofte ikke svarer til børns og unges egne opfattelser af trivsel. Denne problematik er vigtig at forholde sig til, ikke mindst for lærere og pædagoger, som skal kunne forstå og tilrettelægge reflekterede, trivselsfremmende pædagogiske aktiviteter blandt eleverne, ikke mindst i forbindelse med genåbningerne af skolerne.

Vi skelner i denne artikel mellem social trivsel, hvor hverdagen, kammeraterne og familien spiller en væsentlig rolle (WHO, 2010), og faglig trivsel, som knytter sig til selvvurderet læring og personligt, fagligt overskud i forbindelse med undervisningen (Wistoft \& Qvortrup, 2017). Når eleverne selv skal beskrive deres trivsel og mentale sundhed, er deres oplevelser centrale. Derfor spørger vi eleverne, om de savner deres kammerater, skolen, 
fritidsaktiviteterne, lærerne, undervisningen mv. Om de føler sig ensomme. Om de er sammen med kammeraterne fysisk eller digitalt. Og hvorvidt de oplever, at kunne håndtere fjernundervisningen og lære det de skal i hjemmeskolen. Vi spørger også forældrene, om de er bekymrede for deres barn/børns læring og udvikling, om de er bekymrede for, at deres barn/børn bliver smittet af corona og om corona-epidemien påvirker deres barn/ børn mentalt. Endelig spørger vi eleverne, om de oplever, at lærerne er opmærksomme på, hvordan de har det.

\section{Elevernes og forældrenes oplevelse af hjemmeundervisning under corona- skolenedlukningen}

Da vi gennemførte spørgeskemaundersøgelsen om nødundervisning under corona-skolenedlukningen i april 2020, fokuserede vi på elevers og forældres håndtering og oplevelse af hverdagen og nødundervisningen. Mere specifikt var spørgeskemaet designet til at undersøge følgende overordnede temaer i forhold til nødundervisningen:

— Elevernes hverdag og trivsel (6 items)

— Rammer og struktur for skolearbejdet (7 items)

- Kontakt og samarbejde med lærere og klassekammerater (5 items)

— Undervisningsformer og oplevet undervisningskvalitet (9 items)

— Tro på egne evner og mestringsoplevelser (5 items)

- 9. klasse elevers overvejelser om eksamen (4 items)

— Forældrenes rolle og situation ( 7 items)

— Elevernes og forældrenes oplevelse af lærernes og skolens indsats (6 items)

I dette afsnit trækker vi de items frem, som især, direkte eller indirekte, siger noget om elevernes og forældrenes trivsel og mentale sundhed.

Når vi stiller børnene spørgsmål, der omhandler trivsel, så svarer næsten alle, at de savner deres venner. Mange savner også skolen, lærerne og hverdagen med fritidsaktiviteter og socialt samvær. Følgende items peger på deres savn: 
Jeg savner mine venner og kammerater": 92,6 pct. er helt eller delvis enige.

99

Jeg savner mine fritidsaktiviteter": 82,1 pct. er helt eller delvis enige.

99

Jeg savner undervisningen på skolen": 71,2 pct. er helt eller delvis enige.

99

Jeg savner at være sammen med mine lærere": 6o,4 pct. er helt eller delvis enige.

Så godt som alle børnene savner vennerne, skolen og fritiden, og knap en femtedel af dem føler sig ensomme. På spørgsmålet "Jeg føler mig ensom" er 18 pct. helt eller delvis enige, mens 60 pct. er uenige. Der er således nogle, der savner venner, kammerater osv., men ikke føler sig ensomme. Det kan skyldes, at samværet med familien er tydeligt anderledes end før corona. 69,2 pct. er helt eller delvis enige i udsagnet "Jeg laver ekstra mange hyggelige ting sammen med familien". Det kan fortolkes på den måde, at tabet af social trivsel fra samværet med vennerne og i skolen kompenseres af en højere grad af familiemæssigt samvær og deraf følgende trivsel. Under alle omstændigheder er en stor del af børnenes sociale trivsel, der afhænger af at kunne indgå i positive relationer med andre, udfordret, og det er værd at bemærke, at en femtedel er helt eller delvist enige i, at de føler sig ensomme. Ensomhed indgår som item under social trivsel i de nationale trivselsundersøgelser. Den er specielt undersøgt i rapporten "At stå udenfor" fra Børns Vilkår og TrygFonden (2019), som er lavet blandt 2.465 børn i 5. og 8. klasse. Den viser blandt andet, at syv procent af respondenterne tit eller meget tit oplever at føle sig ensomme.

Når følelsen af ensomhed således er relativt høj, kan det blandt andet skyldes, at den fysiske kontakt med vennerne er blevet stærkt reduceret:

99 Jeg mødes med mine venner fysisk (fx udendørs)": 23 pct. er helt eller delvis enige og 65,9 pct. er helt eller delvis uenige. 
Når følelsen af ensomhed ikke er mere udbredt, skyldes det måske, at eleverne på trods af skolelukningerne opretholder en hovedsageligt digital kontakt med deres kammerater:

99

Jeg har en eller flere gange om ugen kontakt med mine klassekammerater": 77,7 pct. er helt eller delvis enige.

99 Jeg mødes med mine venner online (fx på computerspil eller sociale medier)": 68,1 pct. er helt eller delvis enige.

Hvad angår evne-dimensionen i WHO's mentale sundhedsbegreb tyder det på, at mange af børnene er usikre på deres egen læring, hvilket kan hænge sammen med, at de arbejder alene:

99

Jeg har svært ved at vurdere, om jeg når at lære det, jeg skal": 62,6 pct. i 9. klasse er helt eller delvis enige.

99

Jeg løser spørgsmål eller opgaver alene via computeren": 81,7 pct. er helt eller delvis enige.

99

Vi arbejder gruppevis med spørgsmål eller opgaver på computeren": 63,9 pct. siger i lav grad eller slet ikke.

Heroverfor står dog, at et flertal er fortrøstningsfulde og mener, at de nok skal klare det:

99

Jeg har ro på, det skal nok gå”: 55,2 pct. i 9. klasse er helt eller delvis enige.

99 Jeg klarer mig godt med denne slags undervisning": 57,3 pct. er helt eller delvis enige.

99 Lærerne på min skole er opmærksomme på, hvordan jeg har det": 55,7 pct. er helt eller delvis enige.

Endelig spørger vi også eleverne, om deres lærere er opmærksomme på, om de får lavet deres skolearbejde, og på hvordan de har det: 
Lærerne på min skole er opmærksomme på, om jeg laver mit skolearbejde": 77,1 pct. er helt eller delvis enige, mens 6,3 pct. er helt eller delvis uenige.

99

Lærerne på min skole er opmærksomme på, hvordan jeg har det": 55,9 pct. er helt eller delvis enige, mens 17,1 pct. er helt eller delvis uenige.

Eleverne oplever i høj grad, at deres lærere er opmærksomme på dem, både når det kommer til skolearbejdet og til trivsel. Dog er der flere elever, der oplever, at lærerne er mere opmærksomme på, om de laver skolearbejde end på, hvordan de har det. Hvad angår udsagnet om, at deres lærere er opmærksomme på, om de laver deres skolearbejde, indikerer 77,1 pct., at de er helt eller overvejende enige, mens det kun er 55,9 pct., der er helt eller overvejende enige i, at deres lærere er opmærksomme på, hvordan de har det. 17,1 pct. er imidlertid uenige i udsagnet, mens 20,7 pct. svarer hverken/eller og 6,3 pct. 'ved ikke'.

Generelt set kan det være lidt vanskeligt at se, hvor tæt kontakten mellem elever og lærere har været. 34,1 pct. er helt eller overvejende enige i udsagnet om, at "Jeg har kontakt med mindst en af mine lærere hver dag", mens 48,9 pct. er overvejende eller helt uenige i dette udsagn. Der er altså flere elever, der ikke oplever at have daglig kontakt med en lærer, end der er elever, der oplever at have det. Dette tal kan sammenlignes med de svar, lærerne har afgivet i Danmarks Lærerforenings (DLF's) unders $\emptyset$ gelse fra samme periode (DLF, 2020). Her bliver lærerne blandt andet spurgt om deres kontakt med eleverne, og på spørgsmålet "hvis du tænker på perioden med nødundervisning inden påskeferien, hvor enig/uenig er du så i følgende udsagn: Jeg har løbende haft kontakt til alle mine elever?" erklærer 34 pct. af de 2.035 lærere, som har besvaret spørgsmålet, sig meget enige, mens 4.4 . pct. erklærer sig enige (DLF, 202O, s. 4). Selv om udsagnene fra Qvortrup et al. (2020) og fra DLF (2020) ikke kan sammenlignes direkte (der er tydeligvis forskel på udsagnene "Jeg har kontakt med mindst en af mine lærere hver dag" og "Jeg har løbende haft kontakt til alle mine elever"), er det alligevel bemærkelsesværdig, at et flertal af elever ikke oplever at have daglig kontakt med en lærer, mens et flertal af loerere siger, at de har haft løbende kontakt til alle deres elever. Noget tyder på, at elever og lærere har oplevet situationen forskelligt. Det kan blandt andet skyldes, 
at "kontakt" er et vagt begreb, som er brugt forskelligt i vores og $\mathrm{i}$ DLF's undersøgelse.

Eleverne bliver også stillet et åbent spørgsmål med mulighed for at skrive fritekst: "Hvis du tænker på hele situationen omkring skolelukning på grund af corona-virus, hvad savner du så mest - og hvad er du mest glad for?" Når vi kigger på elevernes svar, fremgår det blandt andet, at nogle af dem er bange. Tre tilfældige eksempler lyder: "Jeg er bange for at vi kommer for tidligt i skole igen. Da vi er over 1000 elever samlet på skolen". Eller en anden skriver: "Jeg savner mine venner. Jeg savner at gå i skole. Jeg er bange for at corona-virusset rammer min familie". En tredje: "Jeg savner ikke at være bange".

Andre føler sig imidlertid glade og trygge derhjemme. Som en udtrykker det: "Jeg savner ikke rigtig noget, og jeg er mest glad for at jeg kan stå senere op om morgenen, at få lavet mere i roligere omgivelser, have mere 'mig' tid og jeg er ikke mere nervøs for at blive smittet - det var jeg bange for i skolen".

Ligesom savnet af vennerne går igen i de åbne elevbesvarelser, er angsten for at blive smittet og syg et element, man finder flere gange. Eleverne skriver eksempelvis: "Det er godt at jeg ikke er bange for at blive syg i skolen" eller "Jeg savner mest mine venner. Jeg er glad for at være hjemme, da jeg er bange for at dem jeg holder af bliver smitter og at jeg selv bliver smittet”. Mental sundhed handler som beskrevet også om tilpasning til omstændigheder og udfordringer i hverdagen. En elev beskriver det sådan:

99 Jeg tænker at det skal vel nok gå. Jeg forstår situationen, og hvorfor det har været nødvendigt at lukke skolen. Jeg er lidt bange for om vi har lært nok, i følge med at vi snart skal til eksamen. Jeg savner sammenholdet i vores klasse, og vennerne. I det hele taget savner jeg bare den normale hverdag". En anden skriver: "Jeg er ked af det og bange for hvordan det bliver fremover."

Der er også børn, der svarer, at de er mentalt udfordrede og derfor har det svært, som denne elev: "Jeg har ADHD glæder mig til at se lære og venner. Bange for det bliver hårdt for mig".

Undersøgelsen peger således på, at mange børn tilpasser sig smitterisikoen, men at nogle er bange for smitten og føler sig mest trygge hjemme. Imidlertid kræver det en dybere og mere sy- 
stematisk analyse at afklare, hvad svarene på de åbne spørgsmål mere præcist viser.

Ligesom der i skolen er fokus på differentiering, falder det også her i øjnene, hvor forskelligt børn oplever og reagerer på corona-truslen og hjemmeskole-situationen. De følgende analyser vil gå i dybden med, hvad der karakteriserer familier (mht. uddannelsesmæssig bagrund, geografi mv.), der føler sig særligt mentalt udsatte, og hvilke sammenhænge der er mellem elev- og forældresvar. Vi vil sætte fokus på 'bekymringsfamilierne', hvad angår børnenes faglige og sociale trivsel samt deres risikokompetencer, dvs. oplevelser af at kunne tilpasse sig corona-tidens udfordringer og lære og udvikle sig under de forandrede livs- og skolebetingelser.

Når vi spørger forældrene, falder det i øjnene, at en tredjedel af de forældre, der har svaret, er bekymrede for deres barns læring og udvikling, hvorimod halvdelen ikke er særligt bekymrede. Hvad angår corona-smitte er 40 pct. af forældrene bekymrede for, at deres barn/børn bliver smittet, mens ligeså mange ikke er. På et spørgsmål om børnenes mentale sundhed svarer halvdelen af forældrene, at de er bekymrede for, at corona-epidemien påvirker deres barn mentalt, mens en tredjedel svarer, at de ikke er bekymrede for det. Samme fordeling gør sig gældende, når vi spørger dem, om de er bekymrede for, hvordan corona-epidemien påvirker deres barns/børns situation i forhold til kammerater og fritidsliv. Vi kan altså se, at mange forældre er bekymrede for deres barns/børns trivsel, helbred (smitte) og mentale sundhed. Derfor er det ikke så overraskende, at 86 pct. af forældrene glæder sig til skolen åbner igen. Det skal dog tilføjes, at mange af forældre-udsagnene handler om børnenes mentale sundhed og situation generelt under corona-nedlukningen og ikke specifikt kan relateres til skolelukning og undervisning.

I spørgeskemaet til forældrene er der ét åbent spørgsmål med mulighed for at skrive fritekst: "Beskriv med få ord det værste og det bedste ved den nuværende situation". Vi har i det følgende trukket nogle eksempler ud, uden at vi dog har foretaget en systematisk analyse af fritekstsvarene. En forælder udtrykker det sådan:

99

Der er intet godt ved den nuværende situation. Vores barn er meget trykket af den manglende hverdag med skole og kammerater og er meget frustreret over den måde skolearbejdet skal foregå? Han føler sig lost og har svært ved at 
få den hjælp han har behov for. Det er af yderste nødvendighed for vores barns mentale sundhed, at skolen hurtigst muligt får lov til at tage de ældre elever tilbage, så de kan få et liv igen."

En anden forælder udtrykker sin bekymring på følgende måde:

99 Børnene bliver frataget det liv som børn og unge normalt har, alt i medierne osv. handler om corona. Selvfølgelig skal vi følge de retningslinjer der er udstukket for os. Børnene/ de unge får udsat konfirmationen, og stadig ved de ikke om dem $i$ august kan blive til noget. Og i alt det her brokker de sig ikke, men blot stiltiende accept af hvordan det er. Hører om flere børn/unge vælter mental. Det er en meget høj pris denne corona-krise har betydet for vores børn.”

Om en 'selvkørende' og 'stille pige' siger en forælder:

99 Jeg synes virkeligt mit barns lærere har gjort det godt. Hun er helt selvkørende sammen med dem. Jeg er udelukkende bekymret for det mentale. Hun er ensom og savner sine venner - og det er meget sårbart kun at mødes online, når man er en lidt stille pige."

På spørgsmålet om, hvad der er det bedste og det værste ved corona-situationen, svarer forældrene eksempelvis: "Det bedste: intet. Det værste: at vores barn er understimuleret både fysisk og mentalt".

99 Dejligt med mere tid særligt om eftermiddagen/aftenen uden fritidsaktiviteter... men utrygt ift. ældre familiemedlemmer mv. Vores dreng har desuden en lidt svær tid mentalt, og dette gør det ikke bedre. Mange bekymringer for et 9-årigt hoved."

Som ovenfor nævnt er halvdelen af forældrene imidlertid ikke særligt bekymrede for børnenes situation og trivsel under corona-nedlukningen. Mange udtrykker sig fx positivt omkring den ro og nærhed, der er kommet i familien, når man har mere tid 
sammen. Som en forælder skriver: "Det bedste er at man for en enestående mulighed for at prøve at være rigtigt sammen med sine børn igennem lang tid uden at have en masse aktiviteter på programmet". Eller som en anden forælder skriver: "Bedste fantastisk tid sammen som familie".

Glæden er imidlertid for mange familier tvetydig, idet de både oplever ny og mere 'kvalitetstid' med børnene og samtidig føler sig pressede af at skulle arbejde hjemmefra. Når vi spørger om, hvorvidt situationen gør det svært at balancere arbejdet, børn og familieliv, svarer 51 pct. at det er svært, mens 30 pct. svarer, at ikke er svært.

\section{Statistiske analyser}

Som det fremgår, giver de umiddelbare resultater af undersøgelsen mange tankevækkende svar på, hvordan børn og forældre trivedes i forbindelse med nødundervisningen under corona-nedlukningen. Imidlertid er det også vigtigt at grave et spadestik dybere for at undersøge, hvordan elevernes trivsel og mentale sundhed hænger sammen med andre faktorer under nødundervisningen. Konkret har vi valgt at undersøge sammenhænge med faktorerne: Elevernes oplevelse af undervisningen og af klare rammer og struktur, forældrenes tilfredshed med skolen og lærernes indsats, deres bekymring over børns læring og udvikling, deres oplevelse af at håndtere situationen, og familiernes socioøkonomiske status. For at afdække disse sammenhænge har vi konstrueret følgende indeks med tilhørende Alpha-værdier:

— Mental sundhed $(\mathrm{a}=0,72)$

- Oplevelsen af undervisningen $(\mathrm{a}=0,74)$

— Oplevelsen af klare rammer og struktur $(\mathrm{a}=0,75)$

— Forældres tilfredshed med skolen og lærernes indsats $(\mathrm{a}=0,94)$

— Forældres bekymring over børns læring og udvikling $(\mathrm{a}=\mathrm{O}, 81)$

— Forældres oplevelse af at håndtere situationen $(\mathrm{a}=0,67)$

— Socioøkonomisk status $(\mathrm{a}=0,57)$

I Bilag 1 ser man, hvilke items der indgår i hvert indeks. Indekset er konstrueret på baggrund af en eksplorativ faktoranalyse, som indikerede, hvilke items der korrelerer så meget, at man kan se dem som udtryk for en bagvedliggende latent faktor. Alphaværdierne er acceptable ud fra generelle statistiske kvalitetskriterier, som typisk anbefaler, at disse ligger mellem o,7 og 0,9, 
mens værdier ned til o,5 er brugbare (Cho \& Kim, 2015; Streiner, 2003; Tavakol \& Dennick, 2011). Værdierne fremgår oven for og er et udtryk for, at indeksene er pålidelige.

Regressionsanalyser bruges til at undersøge sammenhænge mellem mellem variable i form af, hvor meget en afhængig variabel ændres, når uafhængige variable ændres (Kelley \& Preacher, 2012; Nathans, Oswald \& Nimon, 2012). Med afsæt i de konstruerede indeks har vi lavet nedenstående regressionsanalyse, som viser sammenhænge mellem niveau af mental sundhed som vores afhængige variabel, og de uafhængige variabler som indgår i tabellen, samt kontrolvariablerne socioøkonomisk status, skole, alder og køn. Koeficienterne i tabellen er således udtryk for, hvor meget indekset for elevernes mentale sundhed ændres, når de uafhængige variabler ændres med én standardafvigelse.

Tabel 1.

\begin{tabular}{|c|c|}
\hline & Bivariat regression \\
\hline Oplevelsen af undervisningen & $0.05^{* * *}$ \\
\hline Oplevelsen af kontakt med lærere og kammerater & $0.17^{* * *}$ \\
\hline Forældres tilfredshed med skolen og lærerne & $0.11^{* * *}$ \\
\hline Forældrebekymringer & $0.12^{* * *}$ \\
\hline Forældres oplevelse af hverdagen & $0.45^{* * *}$ \\
\hline Lav socioøkonomisk status & $-0.11^{* * *}$ \\
\hline Middel socioøkonomisk status & $0.08^{* *}$ \\
\hline Høj socioøkonomisk status & $0.09^{* * *}$ \\
\hline Skole & 0.02 \\
\hline Alder & $-0.05^{* * *}$ \\
\hline Køn & $0.24^{* * *}$ \\
\hline $\begin{array}{l}N=5681 \\
R \text {-Squared }=0,272 \\
{ }^{*} p<0,05,{ }^{* *} p<0,01,{ }^{* * *} p<0,001\end{array}$ & \\
\hline
\end{tabular}

R-squared er på o,272, hvilket betyder, at denne model forklarer ca. en fjerdedel af elevernes mentale sundhed. Dette kan betragtes som forventeligt, eftersom mental sundhed er et komplekst fænomen, som påvirkes af mange faktorer. 


\section{Fortolkning af de statistiske resultater}

Regressionsanalysen kan fortolkes med nogle udvalgte fokuspunkter, som vi her lister op:

For det første er det vigtigt at notere sig, at to af de faktorer, som ifølge de statistiske modeller har en sammenhæng med elevernes mentale sundhed, er elevernes egne oplevelser af at have kontakt med lærere og kammerater samt forældrenes oplevelse af hverdagen. I jo højere grad eleverne oplever kontakt med lærere og kammerater, desto højere vurderer de deres mentale sundhed. Og i jo højere grad forældre oplever hverdagen positivt, desto højere vurderer deres børn, at deres egen mentale sundhed er. Dette fremgår både af den bivariate og den multiple regressionsmodel. Det skal understreges, at resultatet kan fortolkes "begge veje". Man kan ikke afgøre, om elevernes oplevelse af kontakt med lærere og kammerater er årsag til, at de vurderer deres mentale sundhed højt, men det fremgår af analysen, at der er korrelation eller samvarians mellem de to faktorer.

For det andet fremgår det af den statistiske analyse, at elevernes oplevelse af undervisningen ganske vist også hænger sammen med deres mentale sundhed, men at den tilsyneladende er af mindre betydning for elevernes mentale sundhed sammenlignet med de to ovennævnte faktorer, nemlig deres kontakt med lærere og kammerater og forældrenes oplevelse af hverdagen. Hvis man bruger distinktionen mellem social og faglig trivsel, som fx anvendes i de årlige trivselsundersøgelser (Undervisningsministeriet, 2020), er den sociale trivsel vigtigere end den faglige trivsel for elevernes mentale sundhed, i hvert fald under corona-nedlukningens nødundervisning.

For det tredje kan man se, at forældrenes tilfredshed med skolen og lærerne fremstår med en effektstørrelse på o,11 i den bivariate regression og 0,06 i den multiple regression. Det kan fortolkes på den måde, at denne faktor har en betydning for elevernes mentale sundhed, men at dens betydning er mindre end de førstnævnte faktorer.

For det fjerde er det vigtigt at notere sig, at en bivariat regressionsanalyse med spørgsmålet omkring ensomhed og forældrebekymringer resulterer i en koefficient på o,3o og en p-værdi på o,ooo (stærkt signifikant). Dette indebærer, at der er en sammenhæng mellem børns ensomhedsfølelse og forældrenes grad af bekymring; de børn, der føler sig mest ensomme, er også de børn, som har de mest bekymrede forældre.

For det femte viser analysen, at der er en sammenhæng mel- 
lem elevernes mentale sundhed og forældrenes socioøkonomiske status. Elever, der har forældre med lav socioøkonomisk status, vurderer deres egen mentale sundhed lavere end øvrige elever under corona-nedlukningen. Imidlertid er der meget lidt forskel på, hvordan elever med henholdsvis middel og lav socioøkonomisk baggrund vurderer deres mentale sundhed. I den bivariate regression er disse resultater statistisk signifikante. At resultaterne ikke er statistisk signifikante i den multiple regression indikerer imidlertid, at der er andre variable i modellen som har en større forklaringskraft i forhold til mental sundhed. Årsagen hertil kan være manglende besvarelser fra forældre med lav socioøkonomisk status. For mere information om, hvordan socio$\emptyset$ konomisk status er undersøgt, se rapporten "Nødundervisning under corona-nedlukningen - et elev- og forældreperspektiv" (Qvortrup et al., 2020).

For det sjette fremgår det af analyserne, at alder spiller en rolle: Jo ældre børnene er, desto lavere mental sundhed giver de udtryk for. Men det er en meget lille effektstørrelse.

Endelig, for det syvende, kan man se, at også køn har en betydning. I vores undersøgelse er det pigerne, der udtrykker det højeste niveau af mental sundhed, hvilket både er interessant og lidt overraskende i forhold til, at man "normalt" mener, at det er pigerne, der er mest "følsomme" og/eller trives socialt set dårligst. Således er det et gennemgående fund i projektet "Program for Læringsledelse", der blev gennemført i 13 danske kommuner i perioden 2015-2019, at pigerne har en relativt lavere social trivsel end drengene, mens de har den relativt højeste faglige trivsel (Qvortrup, Egelund \& Nordahl, 2016).

\section{Diskussion}

I den indledende fase af analyserne, hvor vi valgte ikke at undersøge, om mental sundhed under corona-nedlukningen hænger sammen med børnenes køn, alder og forældrenes uddannelsesmæssige baggrund, kunne vi se, at børnenes mentale sundhed generelt set er udfordret. Selv om samværet med familien, skovturene og de hjemmebagte boller er hyggeligt, er børnene udfordrede af at savne vennerne, skolen og hverdagen. Vi ved fra anden forskning, at jo længere tid man skal undvære nære sociale relationer, des større er den følelsesmæssige belastning (WHO, 2007). Det er også værd at bemærke, at ca. en tredjedel af forældrene er bekymrede for, om deres barn/børn lærer og udvikler sig, for 
smitterisikoen og for den mentale påvirkning, som corona-nedlukningen og hjemme-isolationen medfører. Ligeledes er det værd at bemærke, at halvdelen af forældrene oplever corona-situationen som en mental udfordring for deres barn/børn. Da vi fra anden forskning ved, at forældre-bekymringer kan 'sætte sig' som angst eller nervøsitet hos børnene (Tanleff-Dunn, 2010), er denne bekymringsfaktor vigtig at lægge mærke til. I et studie fra Virginia har man undersøgt, hvordan børn helt ned i treårsalderen er bekymrede for deres egen krop. Studiet viser, at det ikke er mediernes påvirkning, der er årsag til bekymringer hos børnene, men forældrenes. Navnlig forældrenes selvkontrol og disciplinering har vist sig at være en væsentlig faktor til, at især pigernes selvfølelser er negative (Tanleff, 2010). Dette svarer til fundene i vores undersøgelse af nødundervisning under corona-nedlukningen, at hvad angår ensomhed, har de børn, der føler sig mest ensomme, de mest bekymrede forældre (uanset om det er børnenes ensomhed, der fører til bekymring hos forældrene, eller forældrenes bekymring, der fører til ensomhed for børnene). I forhold hertil kan man både sætte ind i forhold til forældrebekymringer og ved at give de ensomme børn mulighed for at komme ud af ensomheden, $\mathrm{x}$ v ved hjælp af legeaftaler, arrangementer på skolen osv.

I jo højere grad eleverne oplever at have kontakt med lærere og kammerater, desto højere vurderer de deres mentale sundhed, og i jo højere grad forældre oplever hverdagen positivt, desto højere vurderer deres børn egen mentale sundhed. Forældrenes tilfredshed med skolen og lærerne har en sammenhæng med elevernes mentale sundhed - men det er i mindre grad end de øvrige faktorer. Igen kan man fortolke begge veje: At forældrene er tilfredse med skolen, betyder noget for deres børns oplevelse af at føle sig mentalt sunde. Men også: At børnene føler sig mentalt sunde gør, at forældrene er tilfredse med skolen og lærerne. Det kan heller ikke afgøres om elevernes oplevelse af kontakt med deres lærere og kammerater er årsag til, at de vurderer deres mentale sundhed højt, og om forældrenes oplevelse af en positiv hverdag er årsag til, at deres børn oplever mental sundhed. Vi kan alene konstatere, at der er en sammenhæng. Her er det bemærkelsesværdigt, at elevernes oplevelse af undervisningen tilsyneladende har mindre betydning for den mentale sundhed.

Denne undersøgelse bekræfter det, vi allerede ved fra skoleforskningen: At elever, der har forældre med lav socioøkonomisk status, trives fagligt og socialt dårligere end øvrige elever (se fx 
Qvortrup, Egelund \& Nordahl, 2016). Vi kan se, at disse elever vurderer deres egen mentale sundhed lavere end de øvrige elever under corona-nedlukningen. Det er imidlertid vigtigt at påpege, at der er meget lidt forskel på, hvordan elever med henholdsvis middel og høj socioøkonomisk baggrund vurderer deres mentale sundhed. Fra anden forskning ved vi, at elever med lav socio$\emptyset$ konomisk baggrund har problemer i skolen mht. lærerkontakt og klassefællesskab (se fx Qvortrup, Egelund \& Nordahl, 2016). Derfor er der grund til at antage, at eleverne med lav socioøkonomisk baggrund er særligt udsatte, for så vidt at de både mangler forældrenes støtte til skolearbejdet, struktur i hverdagen, kontakt til deres lærere og til fællesskabet med vennerne (Wistoft, Qvortrup, Christensen \& Qvortrup, 2020). Derfor bør man være særlig opmærksom på denne gruppe elever i situationer som den, man oplevede under corona-nedlukningen.

Endelig har vi set på alder og køn: Jo ældre eleverne er, desto lavere mental sundhed giver de udtryk for. Men det er en meget lille effektstørrelse. Sammenholdt med det første punkt er dette interessant: I første punkt konstaterer vi, at der er sammenhæng mellem elevernes oplevelse af kontakt med lærere og kammerater og deres vurdering af deres mentale sundhed - dvs. lav grad af kontakt med lærere og kammerater korrelerer med lav vurdering af mental sundhed. Hvis det samtidig er sådan, at jo ældre eleverne er, desto lavere mental sundhed giver de udtryk for, så viser det, at det kan have været problematisk, at de ældste elever ikke fik lov til at komme tilbage til skole lige så tidligt som de yngste elever.

Andre skoleundersøgelser viser, at selv om drengene klarer sig dårligere end pigerne fagligt, er deres sociale trivsel højere (dette er senest dokumenteret i Jensen, Lorentsen, Andersen, Christiansen \& Hansen, 2020). Det kan måske forklares med de bagvedliggende items for mental sundhed, der eksempelvis handler om at savne venner. Det er også muligt, at pigerne er bedre til at holde kontakt med veninder over digitale platforme. Men dette er ikke omfattet af de data, vi har indsamlet fra nødundervisningen under corona-nedlukningen.

\section{Konklusion}

Med corona-pandemien, der ramte i Danmark i marts 2020, blev skolerne lukket og lærerne, pædagogerne og lederne sat under pres. Eleverne og forældrene skulle indtage nye roller, 
undervisningen skulle foregå hjemme. Kun de meste udfordrede elever (ca. 2 pct.) måtte komme i skole. En større kvantitativ undersøgelse foretaget af en forskergruppe fra Aarhus Universitet og Syddansk Universitet har søgt at afdække, hvad corona-skolenedlukningen kom til at betyde for dels elevernes læring, trivsel og sociale relationer, dels forældrene der skulle balancere mellem arbejde, hjemmeundervisning og familieliv, mens lærerne uden varsel skulle undervise digitalt, samtidig med at undersøgelsen forsøgte at indkredse, hvilke familier der var særligt udsatte, både med hensyn til at klare udfordringerne under nødundervisningen og med hensyn til trivsel og mental sundhed. Gennem skolerens AULA blev et spørgeskema distribueret til elever i 3.-9. klasse og deres forældre i de seks kommuner: Aarhus, Frederikshavn, Hjørring, Lemvig, Odense og Svendborg. Datamaterialet bestod af 5953 gyldige svar fra elever og 4955 svar fra forældre. Artiklen her sætter fokus på spørgsmålene: Hvordan påvirkede corona-nedlukningen elevernes trivsel og mentale sundhed? Hvilke bekymringer havde de selv, og hvilke havde forældrene? Hvordan håndterede elever og forældre skolelukningerne? Hvilke familier følte sig særligt mentalt udsatte? Artiklen præsenterer to typer af resultater: Først præsenteres de umiddelbare svar på en række af spørgsmålene fra spørgeskemaundersøgelsen. Dernæst analyseres sammenhænge mellem data.

Nogle af de vigtige resultater er: Så godt som alle eleverne savner vennerne, skolen og fritiden, og knap en femtedel af dem føler sig ensomme. En vigtig faktor synes at være, at den fysiske kontakt med vennerne er blevet stærkt reduceret. Samtidig er det et problem, at mange af eleverne er usikre på deres egen læring, hvilket synes at hænge sammen med, at de arbejder alene. Ganske vist oplever et flertal af eleverne, at deres lærere er opmærksomme på dem, både når det kommer til skolearbejdet og til trivsel, men der er samtidig knap 20 pct., som ikke oplever, at lærerne er opmærksomme på, hvordan de har det, og næsten halvdelen af eleverne oplever ikke, at de har kontakt med mindst en af deres lærere hver dag. Samtidig udtrykker også en del af forældrene bekymring for deres børns læring og udvikling, og for hvordan corona-nedlukningen påvirker deres børn mentalt.

Hvad angår analysen af de statistiske resultater kan man notere sig en række vigtige sammenhænge:

I jo højere grad eleverne oplever kontakt med lærere og kammerater, desto højere vurderer de deres mentale sundhed, og 
i jo højere grad forældre oplever hverdagen positivt, desto højere vurderer deres børn, at deres egne mentale sundhed er. Der er ligeledes en sammenhæng mellem elevers ensomhedsfølelse og forældrenes grad af bekymring; de elever, der føler sig mest ensomme, er også de elever, som har de mest bekymrede forældre. Denne sammenhæng er ikke overraskende og heller ikke alarmerende: Det er alt andet lige bedre, at forældrene bekymrer sig for deres børn, der ikke trives, end det modsatte: At forældrene ikke bekymrer sig for deres børn, som ikke har det godt. Alligevel er der grund til at hæfte sig ved resultatet. Fra anden mental børnesundhedsforsknings side ved vi nemlig, at forældrebekymringer kan forstærke børnenes bekymringer. Det samme gælder for overdreven forældrekontrol, som også kan gøre børnene ængstelige og selvkritiske.

Også den socioøkonomiske baggrund spiller ind: Elever, der har forældre med lav socioøkonomisk status, vurderer deres egen mentale sundhed lavere end øvrige elever under corona-nedlukningen. Endelig spiller alder og køn en rolle. Jo ældre eleverne er, desto lavere mental sundhed giver de udtryk for. Og tilsyneladende er piger bedre til at håndtere situationer som den under corona-nedlukningen. I vores undersøgelse er det i hvert fald pigerne, der udtrykker det højeste niveau af mental sundhed.

Undersøgelsen bekræfter det, vi allerede ved fra skoleforskningen. Men det er overraskende og vigtigt at være opmærksom på, at corona-nedlukningen forstærker forskellene i så høj grad, som vi har vist, at det er tilfældet. Som den os bekendt eneste undersøgelse af elevernes situation under nødundervisningen, der har eleverne som respondenter, har vi et unikt datamateriale, der siger noget om, hvor dårligt nogle børn trives, når de ikke kommer i skole. Vi har ikke undersøgt, om det "går over", når skolerne er åbnet igen, eller om de børn, der har været ensomme og har haft det mentalt dårligst, har udviklet forskellige strategier for at holde ud - strategier, som de ikke bare lige kan ryste af sig igen. Skolen må derfor være opmærksom på, hvorvidt den forstærkede ulighed forplanter sig, og om corona-nedlukningen har været med til at cementere eller forstærke en socialt betinget ulighed $\mathrm{i}$ trivsel og mental sundhed frem for at reducere den. 


\section{Referencer}

Brooks, S. K., Webster, R. K., Smith L. E., Woodland, L., Wessely, S., Greenberg, N. \& Rubin, G. J. et al. (2020). The psychological impact of quarantine and how to reduce it: rapid review of the evidence. The Lancet, 395(10227), 912-920. https://doi.org/10.1016/So140-6736(20)30460-8.

Burgess, S. \& Sievertsen, H. H. (2020). Schools, skills, and learning: The impact of COVID-19 on education. CEPR Policy Portal, University of Bristol.

Børns Vilkår og Trygfonden (2019). At stå udenfor. Hvordan styrker vi positive foellesskaber blandt børn og unge? København: Børns Vilkår.

Carley-Baxter, L. R., Hill, C. A., Roe, D. J., Twiddy, S. E., Baxter, R. K. \& Ruppenkamp, J. (2013). Does Response Rate Matter? Journal Editors Use of Survey Quality Measures in Manuscript Publication Decisions. Survey Practice, 2(7).

Cho, E. \& Kim, S. (2015). Cronbach's coefficient alpha: Well known but poorly understood. Organizational Research Methods, 18(2), 207-230.

DLF (2020). Undersøgelse blandt lærere og børnehaveklasseledere ifolkeskolen om nødundervisning under COVID-19-nedlukningen (analysenotat).

København: DLF.

Dodge, R., Daly, A., Huyton, J. \& Sanders, L. (2012). The challenge of defining wellbeing. International Journal of Wellbeing, 2(3), 222-235. doi:10.5502/ijw. v2i3.4.

Forgeard, M. J. C., Jayawickreme, E., Kern, M. \& Seligman, M. E. P. (2011). Doing the right thing: Measuring wellbeing for public policy. International Journal of Wellbeing, 1(1), 79-106. doi: 10.5502/ijw.v1i1.15

Jensen, L. B., Lorentsen, A., Andersen, M. B., Christiansen, N. L. S. \& Hansen, I. S. (2020). Udfordringer og succeser i skoleudvikling - når tallene taler. Fællesrapport 2020 for alle kommuner. Aalborg: LSP, Aalborg Universitet.

Kelley, K. \& Preacher, K. J. (2012). On effect size. Psychological methods, 17(2), 137.

Keyes, C. (2002). The mental health continuum: From languishing to flourishing in life. Journal of Health and Behaviour Research, 43, 207-222. doi: 10.2307/3090197

Keyes, C. (2005). Mental illness and/or mental health? Investigating axioms of the complete state model of health. Journal of Consulting and Clinical Psychology, 73(3), 539-548. doi: 10.1037/0022-006X.73-3.539

Keyes, C. (2009). The nature and importance of positive mental health in America's adolescents. I: R. Gilman, E. Huebner \& M. Furlong (red.), Handbook of positive psychology in schools. New York: Routledge.

Keyes, C. L. M., Shmotkin, D. \& Ryff, C. D. (2002). Optimizing well-being: The empirical encounter of two traditions. Journal of Personality and Social Psychology, 82, 1007-1022. doi: 10.1037/0022-3514.82.6.1007

Kong, Q. (2020). Practical Exploration of Home Study Guidance for Students during the COVID-19 Pandemic: A Case Study of Hangzhou Liuxia Elementary School in Zhejiang Province, China (March 31, 2020). Sci Insigt Edu Front, 5(2),557-561. Tilgængelig på SSRN: https://ssrn.com/ abstract $=3565636$ eller http://dx.doi.org/10.2139/ssrn.3565636

La Placa, V., McNaught, A. \& Knight, A. (2013). Discourse on wellbeing in research and practice. International Journal of Wellbeing, 3(1), 116-125. doi:10.5502/ijw.v3i1.7

Nathans, L. L., Oswald, F. L. \& Nimon, K. (2012). Interpreting multiple linear regression: A guidebook of variable importance. Practical Assessment, Research \& Evaluation, $17(9)$. 
Qvortrup, L., Egelund, N. \& Nordahl, T. (2016). Loringsrapport 2015, sammenfatning. FULM. Aalborg: Aalborg Universitetsforlag.

Qvortrup, L., Qvortrup, A., Wistoft, K., Christensen, J. \& Lomholt, R. (2020). Nødundervisning under corona-nedlukningen - et elev-og forceldreperspektiv. Empirisk skole- og dagtilbudsforskning, NCS \#07. Aarhus: Aarhus Universitetsforlag.

Roe, A., Blikstad-Balas, M., Klette, K. og Dalland, C. P. (2020). Hjemmeskole under korona: De minste elevene hadde minst kontakt med loereren. Oslo: Universitet i Oslo. Tilgængelig på: https://www.uv.uio.no/ils/om/aktuelt/ aktuelle-saker/2020/hjemmeskole-under-korona-de-minste-elevenehadde-m.html

Sundhedsstyrelsen (2011). Psykisk mistrivsel blandt 11-15 årige - bidrag til belysning af skolebørns mentale sundhed. København: Sundhedsstyrelsen.

Shils, E. A. \& Finch. H. A. (red.) (1949). Max Weber on the methodology of the social sciences. Glencoe, Ill.: The Free Press.

Streiner, D. L. (2003). Starting at the Beginning: An Introduction to Coefficient Alpha and Internal Consistency. Journal of Personality Assessment, 80(1), 99-103. doi:10.1207/S15327752JPA8001_18

Tanleff-Dunn, S. (2010). Am I too fat to be a princess? Examining the effects of popular children's media on young girls' body image. British Journal of Development and Psychology, 28(2), 413-426.

Tavakol, M. \& Dennick, R. (2011). Making sense of Cronbach's alpha. International journal of medical education, 2,53 .

Undervisningsministeriet (2020). Trivsel i folkeskolen, år 2019. Hentet på: https://www.uvm.dk/statistik/grundskolen/elever/trivselsmaalinger

UNESCO (2020). Handbook on Facilitating Flexible Learning During Educational Disruption: The Chinese Experience in Maintaining Undisrupted Learning in COVID-19 Outbreak. Smart Learning Institute of Beijing Normal University. UNESCO International Research and Training Centre for Rural Education March 15, 2020.

Wang, G., Zhang, Y., Zhao, J., Zhang, J. \& Jiang, F. (2020). Mitigate the effects of home confinement on children during the COVID-19 outbreak. The Lancet, 395(10228), 945-947. https://doi.org/10.1016/ So140-6736(20)30547-X

WHO (2008). Social cohesion for mental well-being among adolescents. Copenhagen: WHO Regional Office for Europe.

WHO (2014). Mental health - a state of well-being. Tilgået den 2. september 2020 på: www.who.int/features/factfiles/mental_health/en/

Wistoft, K. (2009). Sundhedspoedagogik, viden og voerdier. København: Hans Reitzels Forlag.

Wistoft, K. (2010). Health strategies and reservoirs of knowledge. Among adolescents in Denmark. IUHPE - Global Health Promotion, 17(2), 16-24.

Wistoft, K. (2011). Trivsel og selvvcerd. Mental sundhed i skolen. København: Hans Reitzels Forlag.

Wistoft, K. (2019). Trivselsdiskurser - teori-, begrebs- og metodegrundlag. I: M. Sederberg \& M. N. Stolpe, Børn og unges trivsel. Et tvoerprofessionelt ansvar. København: Hans Reitzels Forlag.

Wistoft, K. (2O2O, 7. april). Corona-essay om de 'risikable' unge: Ingen bør mødes med foragt eller fordømmelse - det skaber i yderste konsekvens kun endnu mere smitte. Politiken Sundhed.

Wistoft, K. \& Qvortrup, L. (2017). A Distinction of Two Discourses Concerning Wellbeing. MOJ Public Health, 6(29), 00166. 
Wistoft, K. Qvortrup, L. Christensen, J. \& Qvortrup, A. (2020). Elever der havde det særligt svært med nødundervisningen under coronakrisen. Paideia (i tryk).

Xia, J. (2020). Practical Exploration of School-Family Cooperative Education during the COVID-19 Epidemic: A Case Study of Zhenjiang Experimental School in Jiangsu Province, China (March 15, 2020). SSRN, Elsevier. Tilgængelig på SSRN: https://ssrn.com/abstract=3555523 el. http://dx.doi. org/10.2139/ssrn.3555523

Xie, Z. \& Yang, J. (2020). Autonomous Learning of Elementary Students at Home During the COVID-19 Epidemic: A Case Study of the Second Elementary School in Daxie, Ningbo, Zhejiang Province, China (March 15, 2020). SSRN, Elsevier. Tilgængelig på SSRN: https://ssrn.com/abstract=3555537 el. http://dx.doi. org/10.2139/ssrn.3555537

\section{Bilag 1}

Items der indgår i hvert indeks:

\begin{tabular}{l|l}
\multicolumn{2}{c}{ Mental sundhed } \\
s_20 & Jeg er glad for min nuværende hverdag \\
\hline s_22 & Jeg savner mine venner og kammerater \\
\hline s_23 & Jeg savner at være sammen med mine lærere \\
\hline s_24 & Jeg savner undervisningen på skolen \\
\hline s_25 & Jeg savner mine fritidsaktiviteter
\end{tabular}

\begin{tabular}{l|l}
\multicolumn{2}{c}{ Oplevelse af undervisningen } \\
s_48 & Den er kedelig \\
\hline s_50 & Det er nemt at følge med i undervisningen \\
\hline s_51 & $\begin{array}{l}\text { Jeg kan fint koncentrere mig om de skoleaktiviteter, jeg skal lave i løbet } \\
\text { af dagen }\end{array}$ \\
\hline s_52 & Jeg kommer til at bruge al for meget tid på andre ting end skolen \\
\hline s_53 & Lærerne klarer situationen godt
\end{tabular}

\section{Oplevelse af kontakt med lærere og kammerater}

\begin{tabular}{l|l} 
s_29 & Jeg ved for det meste, hvad lærerne vil have mig til at lave \\
\hline s_30 & Lærerne på min skole er opmærksomme på, om jeg laver mit skolearbejde \\
\hline s_31 & Lærerne på min skole er opmærksomme på, hvordan jeg har det \\
\hline s_33 & Jeg har en eller flere gange om ugen kontakt med mine klassekammerater \\
\hline s_35 & Hvis der er opgaver, jeg ikke forstår, er det nemt at få hjælp fra en lærer \\
\hline s_36 & $\begin{array}{l}\text { Hvis der er opgaver, jeg ikke forstår, er det nemt at få hjælp fra en kam- } \\
\text { merat }\end{array}$ \\
\hline s_38 & Jeg har kontakt med mindst en af mine lærere hver dag
\end{tabular}




\section{Forældres tilfredshed med skolen og lærernes indsats}

\begin{tabular}{l|l} 
s_70 & Skolen og dens ledelse har informeret os godt \\
\hline s_71 & Lærerne har håndteret situationen med stor dygtighed \\
\hline s_72 & Lærerne har håndteret situationen med stor entusiasme \\
\hline s_73 & Vores barn/børn har fået god støtte fra skolen \\
\hline s_74 & $\begin{array}{l}\text { Vi har fået god hjælp til at håndtere situationen i forhold til børnenes } \\
\text { skolegang }\end{array}$
\end{tabular}

\section{Forældrebekymringer}

\begin{tabular}{l|l} 
s_75 & Vi er bekymrede i forhold til vores barns/børns læring og udvikling \\
\hline s_77 & Vi er bekymrede for, at vores barn/børn bliver smittet af corona-virus \\
\hline s_78 & $\begin{array}{l}\text { Vi er bekymrede for, hvordan corona-epidemien påvirker vores } \\
\text { barn/børn mentalt }\end{array}$ \\
\hline s_79 & $\begin{array}{l}\text { Vi er bekymrede for, hvordan corona-epidemien påvirker vores } \\
\text { barns/børns situation i forhold til kammerater og fritidsliv }\end{array}$
\end{tabular}

\section{Forældres oplevelse af hverdagen}

\begin{tabular}{l|l} 
s_66 & Det er let at få hverdagen til at hænge sammen \\
\hline s_68 & Vores barn/børn keder sig \\
\hline s_69 & Vores barn/børn glæder sig til, at skolen åbner igen \\
\hline s_76 & Situationen gør det svært at balancere arbejde, barn/børn og familieliv \\
\hline s_80 & Vi glæder os til, at skolerne åbner igen
\end{tabular}




\section{Learning Tech - Tidsskrift for læremidler, didaktik og teknologi}

Udgives af Læremiddel.dk

Learning Tech er et forskningstidsskrift, hvor alle artikler er forskerbedømt i form af dobbeltblindt peer review. Tidsskriftet bringer artikler, der rammer genstandsfeltet mellem læremidler, didaktik og teknologi, og hensigten er at spille en betydelig rolle som platform for den voksende skandinaviske læremiddelforskning.

\section{Redaktion}

Stig Toke Gissel, UCL Erhvervsakademi og Professionshøjskole (ansvarshavende redaktør)

Bettina Buch, Professionshøjskolen Absalon

Hildegunn Juulsgaard Johannesen, University College Syd

Ove Christensen, Professionshøjskolen Absalon

Peter Holmboe, University College Syd

René Boyer Christiansen, Professionshøjskolen Absalon

Thomas R. S. Albrechtsen, University College Syd

\section{Redaktionssekretær}

Trine Ellegaard, UCL Erhvervsakademi og Professionshøjskole

\section{Temaredaktion}

Bettina Buch, Professionshøjskolen Absalon

Stig Toke Gissel, UCL Erhvervsakademi og Professionshøjskole

Stine Reinholdt Hansen, UCL Erhvervsakademi og Professionshøjskole

\section{Design og grafisk tilrettelæggelse}

Trefold - grafisk design og kommunikation

\section{Tryk}

Narayana Press, Gylling

ISSN 2445-7981 (Tryk)

ISSN 2445-6810 (Online)

\section{Rettigheder}

(c) 2020 Læremiddel.dk og forfatterne

\section{Kontakt}

Læremiddel.dk, Niels Bohrs Allé 1,5230 Odense M

www.laeremiddel.dk

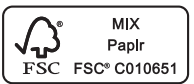

